\title{
Developing Common Competencies for Southeast Asian General Dental Practitioners
}

\author{
Supachai Chuenjitwongsa, PhD; Suchit Poolthong, PhD; Alison Bullock, PhD; \\ Richard G. Oliver, PhD
}

Abstract: Current policy in Southeast Asian dental education focuses on high-quality dental services from new dental graduates and the free movement of dental practitioners across the region. The Southeast Asian Nations (ASEAN) Dental Councils have proposed the "Common Major Competencies for ASEAN General Dental Practitioners" to harmonize undergraduate dental education. This article discusses how the ASEAN competencies were developed and established to assist the development of general dental practitioners with comparable knowledge, skills, and attitudes across ASEAN. The competencies were developed through four processes: a questionnaire about current national oral health problems, a two-round Delphi process that sought agreement on competencies, a panel discussion by representatives from ASEAN Dental Councils, and data verification by the representatives after the meeting. Key themes of the ASEAN competencies were compared with the competencies from the U.S., Canada, Europe, Australia, and Japan. A total of 33 competency statements, consistent with other regions, were agreed upon and approved. Factors influencing the ASEAN competencies and their implementation include oral health problems in ASEAN, new knowledge and technology in dentistry, limited institutional resources, underregulated dental schools, and uneven distribution of dental practitioners. The ASEAN competencies will serve as the foundation for further developments in ASEAN dental education including policy development, curriculum revision, quality assurance, and staff development. Collaboration amongst stakeholders is essential for successful harmonization of ASEAN dental education.

Dr. Chuenjitwongsa is Lecturer in Dental Education, Department of Biochemistry, Faculty of Dentistry, Chulalongkorn University, Bangkok, Thailand; Dr. Poolthong is Assistant Professor, Department of Operative Dentistry, Faculty of Dentistry, Chulalongkorn University, Bangkok, Thailand; Dr. Bullock is Professor, Cardiff Unit for Research and Evaluation in Medical and Dental Education, School of Social Sciences, Cardiff University, Cardiff, UK; and Dr. Oliver is Professor, Postgraduate Medical and Dental Education, Wales Deanery, Cardiff University, Cardiff. Direct correspondence to Dr. Supachai Chuenjitwongsa, Department of Biochemistry, Faculty of Dentistry, Chulalongkorn University, Bangkok, Thailand, 10100; +66 (0)2218 8670; supachai.c@chula.ac.th.

Keywords: dental education, competency-based education, Southeast Asia, general dental practitioners

Submitted for publication 10/13/16; accepted 2/20/17

doi: $10.21815 / J D E .017 .067$

$\mathrm{T}$ The Association of Southeast Asian Nations (ASEAN) is a political and economic organization of ten countries: Brunei Darussalam, Cambodia, Indonesia, Laos, Malaysia, Myanmar, Philippines, Singapore, Thailand, and Vietnam. It aims to support free trade and free movement of people among its member states, peace and stability in the region, and collaboration on matters of common interests. ${ }^{1}$ An ASEAN Mutual Recognition Arrangement (MRA) on Dental Practitioners was signed by the ministers of member states in 2009. The MRA focuses on strengthening professional capabilities by promoting flow of relevant information and exchanging expertise, experiences, and best practices suited to the specific needs of ASEAN member states. ${ }^{2}$ Implementation of the MRA is overseen and regularly discussed by the ASEAN Joint Coordinating Committee on Dental Practitioners (AJCCD); one of its main concerns is ensuring that standards of dental services provided by new dental graduates are comparably high across the ASEAN member states. The aim of dental education is to prepare students to be competent dentists able to meet the public's oral health care needs. ${ }^{3}$ The identification of competencies is a core task when developing dental education to meet those societal needs. ${ }^{4}$ An agreed-upon set of competencies would support dental schools in ASEAN to deliver high-quality undergraduate dental education.

In North America and Europe, competencies for new dental graduates have been developed and implemented..$^{5-8}$ However, in Southeast Asia, such competencies for ASEAN dental practitioners had not yet been established. Some ASEAN countries have developed competencies for dental graduates being implemented at dental schools. In a few ASEAN countries, national dental competencies are being developed more gradually due to challenges arising 
from socioeconomic problems, politics, or staff shortages. Additionally, as the local sociocultural context and oral health problems influence how dental education is delivered, ${ }^{4}$ the profile and characteristics of ASEAN dental graduates may be different from graduates in North America or Europe. Thus, competencies for ASEAN dental practitioners needed to be identified and developed to ensure that new dental graduates meet expectations, which in turn will enable the free movement of dental practitioners across the ASEAN by 2020.

The ASEAN Dental Forum (ADF) — supported by the AJCCD and the Faculty of Dentistry, Chulalongkorn University, Thailand — was established in response to the desire to agree on competencies for ASEAN dental practitioners. The first ADF was held in May 2015. Twenty-six representatives of dental schools and the Dental Councils of the ASEAN member states signed a declaration and agreed to work together, on the basis of trust and willingness, to achieve the harmonization of dental education across the ASEAN region. The primary goals of the ASEAN collaboration are to develop common competencies for the safe and independent practice of ASEAN general dental practitioners and to develop an agreed-upon core ASEAN undergraduate dental curriculum. $^{9}$ At the second ADF, held in August 2016, the representatives from the Dental Councils of ASEAN member states proposed "Common Major Competencies for ASEAN General Dental Practitioners" to assist the development of comparable general dental practitioners across ASEAN.

This article discusses how these competencies were developed and agreed upon, and it discusses factors influencing dental curricula in ASEAN. Recommendations for the policymakers and dental schools in ASEAN are also made.

\section{Materials and Methods}

The article was developed using secondary data (based on the ADF report) and did not require Institutional Review Board approval/exemption. The process for defining a set of competencies and characteristics that describe ASEAN general dental practitioners consisted of four stages.

\section{Stage One, March 2016}

This stage addressed current ASEAN oral health status and undergraduate dental curricula. A questionnaire with questions about current national oral health problems and undergraduate dental education in ASEAN was developed based on official documents reporting competencies for general dentists ${ }^{5-8,10}$ and undergraduate curriculum structure. ${ }^{11}$ It aimed to identify the common oral health issues that ASEAN dental practitioners regularly encounter and in which they need to be competent and to determine whether the current topics taught in ASEAN undergraduate dental curricula are sufficient for comprehensive practice on graduation.

The questionnaire was verified by two experts in dental education and was distributed to representatives of the Dental Council of each member state during the AJCCD meeting in March 2016. The representatives were individuals involved in dental education policy development and were selected by the Dental Council committees of their country. The representatives from Dental Councils of ASEAN member states were invited to rank the importance of addressing various oral health conditions in their countries using a four-point scale from $4=$ very important to $1=$ not important. They were also asked whether particular topics were missing from or available in undergraduate dental curricula in their countries. The data were analyzed using descriptive statistics.

\section{Stage Two, June-July 2016}

This stage aimed to develop a list of competencies informed by the results from Stage One. The Delphi method was used with members of Dental Councils across ASEAN. The Dental Council of each member state selected one representative (who had been regularly involved in curriculum development for at least five years or had an education-related qualification) to complete the questionnaire. Delphi is an iterative process using a questionnaire that seeks to obtain expert agreement without the need to meet. ${ }^{12}$ This process makes it useful for gathering information across geographical barriers. ${ }^{13}$

In this study, two Delphi rounds were used to develop consensus. Lists of competencies for new dental graduates from the U.S., ${ }^{5}$ Europe, ${ }^{6}$ Canada, ${ }^{7}$ Australia, ${ }^{10}$ and Japan ${ }^{14}$ were analyzed thematically, categorized, and used for developing the Delphi questionnaire. The Stage One results were attached to the questionnaire. The appropriateness of the Delphi questionnaire was verified by the same experts as used in Stage One. The data were analyzed using descriptive statistics. (The Stage One and Stage Two questionnaires are available from the corresponding author.) 


\section{Stage Three, Aug. 2016}

This stage involved finalizing the competencies for ASEAN general dental practitioners. One weakness of Delphi is a lack of clarification and discussion amongst the panelists. ${ }^{15}$ To improve the quality of the Delphi results, a second ADF meeting was held to allow representatives from the Dental Council of each member state to discuss three issues based on the results from the earlier stages: 1) the oral health needs of the ASEAN countries and undergraduate dental curricula in ASEAN; 2) a list of common competencies for ASEAN general dental practitioners; and 3) factors to consider when implementing the competencies.

Prior to each discussion session, a one-hour lecture provided basic information about competencybased dental education. At the end of the meeting, the representatives proposed the "Common Major Competencies for ASEAN General Dental Practitioners" and signed the Bangkok Declaration of $17^{\text {th }}$ August 2016. The ASEAN competencies were triangulated with the lists of competencies for new dental graduates from other regions used in Stage Two and summarized into a meeting report.
Stage Four, Sept. 2016 to Jan. 2017

This stage involved verification of the competencies for ASEAN general dental practitioners. Another limitation of the Delphi method is that the expert agreements may not be generalizable in a wider context, so presenting the results to an interest group and gaining its feedback can improve the quality of the Delphi results. ${ }^{16}$ Thus, the meeting report containing the competencies was presented to, discussed, and verified by the AJCCD on September 27, 2016. As a part of continuous development of the ASEAN competencies, an ASEAN Dental Student Forum will be held in 2018 to provide student input. Prior to implementation of the ASEAN competencies, as suggested by the AJCCD, the actions or activities dental graduates should be able to demonstrate for each competency statement will be defined.

The ASEAN competencies were sent to the Dental Council of each member state for consultation and approval between October 2016 and January 2017. Finally, the ASEAN competencies were endorsed and were announced by the AJCCD on January 31, 2017 (Table 1).

Table 1. ASEAN competencies approved and announced by ASEAN Joint Coordinating Committee on Dental Practitioners on January 31, 2017

Competency Statement

Theme

1. Demonstrate ethical and professional behaviors that are in accordance with the local codes of conduct for dental professionals.

2. Provide dental care in compliance with the principles of ethics and jurisprudence.

3. Recognize patients' rights, demonstrate appropriate care, and respect patients and colleagues without discrimination.

4. Practice within one's competence and know when to consult and/or refer.

5. Communicate effectively with patients and their caregivers, colleagues, and the public.

6. Critically evaluate and apply best up-to-date research evidence in managing oral health.

7. Apply knowledge of the scientific basis of dentistry, including the relevant biomedical and psychosocial sciences, to the practice of dentistry in compliance with the correct academic principles.

8. Display commitment to lifelong learning for professional development and maintain high-quality care for patients and the community.

9. Lead and/or participate with dental and/or other health care team in dental and general health promotion.

10. Manage and maintain a safe working environment including patient safety and effective cross infection control.

11. Organize and manage dental practice office/clinic.

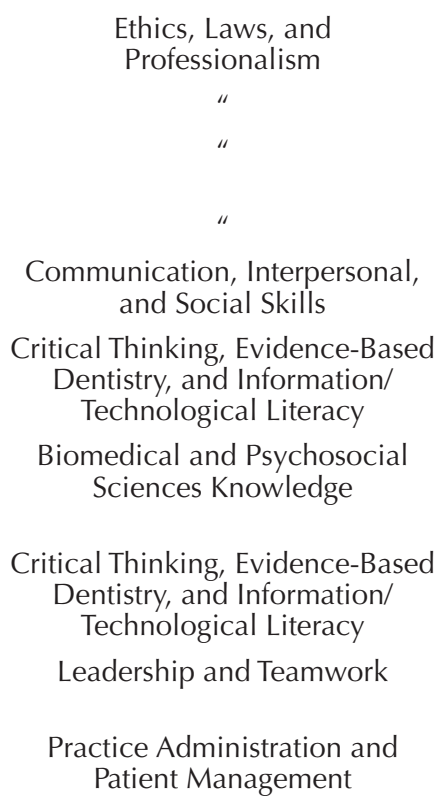
and Social Skills

Critical Thinking, Evidence-Based Dentistry, and Information/ Technological Literacy

Biomedical and Psychosocial Sciences Knowledge

Critical Thinking, Evidence-Based

Dentistry, and Information/ Technological Literacy

Leadership and Teamwork

Practice Administration and Patient Management 
Table 1. ASEAN competencies approved and announced by ASEAN Joint Coordinating Committee on Dental Practitioners on January 31, 2017 (continued)

Competency Statement

Theme

12. Identify patient's chief complaints and obtain complete medical, dental, and psychosocial history.

13. Perform appropriate clinical examination, necessary diagnostic tests, and radiographic examination/investigation.

14. Obtain and interpret all findings in order to arrive at an accurate diagnosis.

15. Formulate appropriate initial, differential, and final diagnoses based on interpretation of the clinical, laboratory, and radiographic findings.

16. Keep accurate, systematic, and current patient medical/dental records in compliance with international standards and local data protection regulation/legislation.

17. Formulate a comprehensive treatment and/or referral plan.

18. Apply a patient-centered approach to adjust treatment plans to suit patients' needs and values according to standards of care.

19. Recognize and manage medical and dental emergencies and perform basic life support.

20. Manage patient's pain and anxiety by using both pharmacological and nonpharmacological techniques.

21. Manage carious and non-carious lesions and provide treatment when indicated.

22. Manage pulpal and periapical diseases and perform non-surgical root canal treatment on uncomplicated single- and multi-rooted teeth.

23. Manage periodontal conditions and diseases and provide nonsurgical periodontal treatment when indicated.

24. Manage oral surgery treatment needs and perform minor oral surgical procedures.

25. Recognize and manage common oral mucosal lesions.

26. Manage patients with prosthodontic treatment needs and provide suitable removable and/or fixed prostheses.

27. Manage patients with abnormal craniofacial anomalies and malocclusion.

28. Manage patients with masticatory disorders/diseases and/or orofacial pain.

29. Recognize and manage patients with special needs.

30. Recognize indication of patient suitable for implant treatment and its complications and make appropriate referral.

31. Monitor and evaluate treatment outcomes and provide additional action as necessary.

32. Use the concepts of holistic health care, health promotion, disease prevention, and public health management to educate and promote oral health of the individuals and the community, and be able to evaluate results.

33. Recognize the oral health status and importance of the health service systems in a culturally diverse society.

Note: These competencies refer to general dental practice and include management of patients of all ages including those with specia needs (e.g., patients who are physically and/or intellectually challenged or who may have complex medical conditions that may make oral health' care more complex).

\section{Glossary of Key Words}

- "Recognize" means to perceive and identify, to realize and be able to identify the impact of an apparent patient management issue or incident.

- "Manage" means being able to evaluate patients' and dentists' circumstances, statuses, and conditions; provide an initial diagnosis; arrange for patients' care and/or treatment, which can range from no intervention to obtaining advice from a physician and/or another dentist; make a referral; provide initial treatment; and provide competent treatment independently.

- "Appropriate" refers to the level of practice that offers maximum benefit to patients with respect to their oral/general health condition, circumstances, and other determinants of oral/general health. Also refers to dentists' clinical competence and expertise.

- "Competence" is a combination of knowledge, skills, and professional and personal attributes of good dentists; also refers to an ability to work safely and independently (without direct supervision) in a real professional context.

- "Professional competencies" (summarized in competency statements) refer to the abilities a new graduate dentist needs in order to practice as a general dentist. 


\section{Results and Discussion}

Of the ten ASEAN countries, nine completed the first questionnaire. Brunei Darussalam requested to be excluded from the competency development process as currently the country has no undergraduate dental education. Eight member states completed the two-round Delphi (Philippines completed only the first-round Delphi) and signed off the final competency statements. An additional three observers (from Indonesia, Singapore, and Thailand) attended the second ADF meeting. The representative from Laos was unavailable.

\section{Common Competencies for ASEAN General Dental Practitioners}

The representatives discussed and proposed 33 common major competencies. Professional competencies, expressed in competency statements, are the abilities that new graduate dentists need in order to practice as a general dentist. Competence is a combination of knowledge, skills, professional attitude, and personal attributes of good dentists. Competence also refers to an ability to work safely and independently (without direct supervision) in a real professional context. The proposed competencies (Table 1) refer to general dental practice and include the management of patients of all ages including those with special needs (e.g., patients who are physically and/or intellectually challenged or who may have complex medical conditions that may make oral health care more complex).

The representatives agreed to convene as a permanent expert panel and continue working on the competencies. The expectation is that the competencies will be reviewed and revised every five years through a consultation process. This process will be undertaken concurrently with the dental competencies revision process in some countries (e.g., Thailand) where the national quality assurance system requires dental schools to revise their curricula every five to six years.

While details of each competency in the form of supporting competencies are required for implementing competencies at the institutional or curricular level, the representatives agreed that, in this early stage of harmonizing ASEAN dental education, major competencies alone are adequate for the AJCCD to set up future regional policies to facilitate free movement of dental practitioners and Dental Councils to develop their own national standards and systems to support curriculum revision and development. The 33 competency statements were grouped into 22 themes based on foundation principles (e.g., statements 12 to 18 were grouped into Assessment, Diagnosis, and Treatment Planning). These 22 themes of the ASEAN competencies were compared with the competencies for new dental graduates from North America, Europe, Australia, and Japan (Table 2).

\section{Dental Practitioners as Part of Health Care System}

Most themes of the ASEAN competencies are consistent with the competencies for dental graduates in other regions. The Health Care System (item 21 in Table 2) is one important theme for ASEAN, but it is not mentioned in the competencies in some countries (e.g., Canada, Japan). Due to the shortage of dentists in most ASEAN countries, new dental graduates are required to work for the government to serve the population, especially concentrating in underserved areas.

In this situation, knowledge of the national and local health care system as well as an ability to work within such a system is necessary for practice. Similarly, in some European countries, dental graduates have a narrow (or even single) career choice in which graduates can only work for the government before they develop their own specialties later. ${ }^{17}$ Those graduates may need competencies relating to the health care system to work effectively in the government sector.

\section{Oral Health Status in ASEAN}

The common oral health problems in ASEAN as agreed upon by representatives of the Dental Councils of ASEAN member states are listed in Table 3. According to the participants, dental caries and periodontal diseases are the most common oral health problems. These conditions have a significant public health impact in the region. ${ }^{18}$ Pulpal and periapical diseases are very common in ASEAN; however, there is a paucity of reports highlighting these problems. As pulpal and periapical diseases often develop from untreated dental caries and are sometimes caused by periodontal diseases (endo-perio lesions), their high prevalence implies that oral health prevention and promotion of these conditions are inadequate. Additionally, the majority of ASEAN countries are 
Table 2. Key themes of the ASEAN competencies compared with competencies for new dental graduates in the U.S., Canada, Europe, Australia, and Japan

\begin{tabular}{|c|c|c|c|c|c|c|}
\hline Theme & \multirow{2}{*}{$\frac{\text { ASEAN }}{\mathrm{O}}$} & \multirow{2}{*}{$\frac{\text { U.S. }}{\mathrm{O}}$} & \multirow{2}{*}{$\begin{array}{c}\text { Canada } \\
\mathrm{O}\end{array}$} & \multirow{2}{*}{$\frac{\text { Europe }}{\mathrm{O}}$} & \multirow{2}{*}{$\frac{\text { Australia }}{\mathrm{O}}$} & \multirow{2}{*}{$\frac{\text { Japan }}{\mathrm{O}}$} \\
\hline 1. Ethics, Laws, and Professionalism & & & & & & \\
\hline 2. Communication, Interpersonal, and Social Skills & $\mathrm{O}$ & $\mathrm{O}$ & $\mathrm{O}$ & $\mathrm{O}$ & $\mathrm{O}$ & $\mathrm{O}$ \\
\hline $\begin{array}{l}\text { 3. Critical Thinking, Evidence-Based Dentistry, and Information/ } \\
\text { Technological Literacy }\end{array}$ & $\mathrm{O}$ & $\mathrm{O}$ & $\mathrm{O}$ & $\mathrm{O}$ & $\mathrm{O}$ & $\mathrm{O}$ \\
\hline 4. Biomedical Sciences Knowledge & $\mathrm{O}$ & $\mathrm{O}$ & $\mathrm{O}$ & $\mathrm{O}$ & $\mathrm{O}$ & $\mathrm{O}$ \\
\hline 5. Leadership and Teamwork & $\mathrm{O}$ & $\mathrm{O}$ & $x$ & $\mathrm{O}$ & $\mathrm{O}$ & $\mathrm{O}$ \\
\hline 6. Practice Administration and Patient Management & $\mathrm{O}$ & $\mathrm{O}$ & $\mathrm{O}$ & $\mathrm{O}$ & $\mathrm{O}$ & $\mathrm{N}$ \\
\hline 7. Assessment, Diagnosis, and Treatment Planning & $\mathrm{O}$ & $\mathrm{O}$ & $\mathrm{O}$ & $\mathrm{O}$ & $\mathrm{O}$ & $\mathrm{O}$ \\
\hline 8. Medicine and Medical Emergency & $\mathrm{O}$ & $\mathrm{O}$ & $\mathrm{O}$ & $\mathrm{O}$ & $\mathrm{O}$ & $\mathrm{O}$ \\
\hline 9. Cariology and Restoration & $\mathrm{O}$ & $\mathrm{O}$ & $\mathrm{O}$ & $\mathrm{O}$ & $\mathrm{O}$ & $\mathrm{O}$ \\
\hline 10. Endodontology & $\mathrm{O}$ & $\mathrm{O}$ & $\mathrm{O}$ & $\mathrm{O}$ & $\mathrm{O}$ & $\mathrm{O}$ \\
\hline 11. Periodontology & $\mathrm{O}$ & $\mathrm{O}$ & $\mathrm{O}$ & $\mathrm{O}$ & $\mathrm{O}$ & $\mathrm{O}$ \\
\hline 12. Oral and Maxillofacial Surgery & $\mathrm{O}$ & $\mathrm{O}$ & $\mathrm{O}$ & $\mathrm{O}$ & $\mathrm{O}$ & $\mathrm{O}$ \\
\hline 13. Oral Medicine & $\mathrm{O}$ & $\mathrm{O}$ & $\mathrm{O}$ & $\mathrm{O}$ & $\mathrm{O}$ & $\mathrm{N}$ \\
\hline 14. Prosthodontics & $\mathrm{O}$ & $\mathrm{O}$ & $\mathrm{O}$ & $\mathrm{O}$ & $\mathrm{O}$ & $\mathrm{O}$ \\
\hline 15. Orthodontics & $\mathrm{O}$ & $\mathrm{O}$ & $\mathrm{O}$ & $\mathrm{O}$ & $\mathrm{O}$ & $x$ \\
\hline 16. Masticatory System and Occlusion & $\mathrm{O}$ & $\mathrm{O}$ & $\mathrm{O}$ & $\mathrm{O}$ & $\mathrm{O}$ & $\mathrm{O}$ \\
\hline 17. Special Needs Patients (e.g., pediatric, elderly, disabled) & $\mathrm{O}$ & $\mathrm{O}$ & $\mathrm{O}$ & $\mathrm{O}$ & $\mathrm{O}$ & $\mathrm{O}$ \\
\hline 18. Multidisciplinary Topics (e.g., implant, trauma) & $\mathrm{O}$ & $\mathrm{O}$ & $\mathrm{O}$ & $\mathrm{O}$ & $\mathrm{O}$ & $x$ \\
\hline 19. Treatment Outcome Evaluation & $\mathrm{O}$ & $\mathrm{O}$ & $\mathrm{O}$ & $\mathrm{O}$ & $\mathrm{O}$ & $\mathrm{O}$ \\
\hline 20. Oral Health Prevention and Promotion/Community Dentistry & $\mathrm{O}$ & $\mathrm{O}$ & $\mathrm{O}$ & $\mathrm{O}$ & $\mathrm{O}$ & $\mathrm{O}$ \\
\hline 21. Health Care System & $\mathrm{O}$ & $\mathrm{O}$ & $x$ & $\mathrm{O}$ & $\mathrm{O}$ & $x$ \\
\hline $\begin{array}{l}\text { 22. Other (e.g., patient abuse and neglect, substance abuse, } \\
\text { smoking cessation) }\end{array}$ & $x$ & $\mathrm{O}$ & $\mathrm{O}$ & $x$ & $x$ & $x$ \\
\hline $\begin{array}{l}\mathrm{O}=\text { included as a major or supporting competency statement } \\
\mathrm{N}=\text { not clearly stated in a competency statement (e.g., implied or refer } \\
\mathrm{X}=\text { not included as a competency statement }\end{array}$ & to bu & ectl & & & & \\
\hline
\end{tabular}

low/low-middle income, resulting in people having limited access to dental services. ${ }^{19}$ One ASEAN country's representative noted that current dental practitioners tend to focus on providing treatment rather than promotion and prevention procedures (e.g., oral hygiene instruction). Untreated dental caries, periodontal disease, and pulpal and periapical disease can result in tooth loss, which was ranked as the fourth most important oral health problem in ASEAN. Additionally, the prevalence of tooth loss could relate to the high level of maxillofacial trauma caused by accidents and violence in some ASEAN countries. ${ }^{18}$

In these responses from the ASEAN Dental Councils, other oral health problems in ASEAN were distributed unevenly. For example, while ASEAN has the highest prevalence of oral cancers (especially squamous cell carcinoma) compared with other regions, such conditions are common only in particular
Table 3. Common oral health problems in ASEAN

\begin{tabular}{lc} 
Oral Health Problem & $\begin{array}{c}\text { Mean } \\
\text { Score }\end{array}$ \\
\hline 1. Dental caries & 3.78 \\
2. Periodontal diseases & 3.56 \\
3. Pulpal and periapical diseases & 3.44 \\
4. Tooth loss/missing & 3.33 \\
5. Oral and maxillofacial surgery problems & 3.33 \\
6. Diseases or abnormalities of oral mucosa & 3.00 \\
7. Diseases or abnormalities of the masticatory & 3.00 \\
8. System; oral and facial pain & \\
8. Tooth surface loss and sensitivity & 2.89 \\
9. Abnormal growth and development of skulls, & 2.89 \\
\multicolumn{2}{l}{ facial bones, and jaws }
\end{tabular}

10. Systemic-related oral and maxillofacial diseases 2.89

Note: Scores were on rating scale of $4=$ very important, 3 =important, $2=$ less important, and $1=$ not important. These common oral health problems were agreed upon and rated for importance by representatives of the Dental Councils of ASEAN member states. 
countries (e.g., Myanmar) where oral malignancies caused by chewing betel nuts or tobacco-containing substances are high. ${ }^{18,20}$ The tobacco-related problems in other ASEAN countries are similar to those in developed countries. In Singapore and Thailand, there is a growing number of oral health problems related to high-socioeconomic status population in urban areas (e.g., tooth surface loss caused by carbonated drinks). In Indonesia and Philippines, systemic diseases such as diabetes that have an impact on oral health are increasing.

\section{Other Health Problems}

Some issues such as drug addiction and smoking have been perceived as an important part of predoctoral dental education. ${ }^{21,22}$ However, these issues may vary by area and could be influenced by local cultures implying that dental graduates may not regularly encounter them. Additionally, solving drug addiction and smoking may require a holistic approach from various health care professionals and other stakeholders. Dental graduates may only need to be aware of these problems and have basic knowledge and an ability to work within a multi-professional health care team. Hence, the representatives suggested that, instead of defining a separate competency statement, competencies related to these topics could be integrated into other themes focusing on the roles of dental practitioners in a health care team (e.g., community dentistry, preventive dentistry).

\section{Factors Influencing Dental Curricula in ASEAN}

During the competencies development process, a number of issues in relation to the quality of undergraduate dental curricula, graduates, and oral health services in ASEAN were discussed by the ASEAN Dental Councils. Following are overviews of those issues.

Advances in scientific knowledge and educational innovations. New scientific knowledge, technology, and contemporary educational concepts in dentistry were discussed including evolving biomedical science informing multidisciplinary dental research and practice, ${ }^{23}$ influences of technology in supporting dental education such as blendedlearning and social media; ${ }^{24,25}$ and competency-based education, which is generally believed to enhance the quality of dental graduates for society over that of traditional discipline-based education. ${ }^{26,27} \mathrm{Un}$ - dergraduate dental education as well as roles and competencies of educators need to be developed congruent with the educational changes. ${ }^{11,28}$ However, ASEAN undergraduate dental curricula and dental educators have not yet fully adapted to these changes. The main reasons relate to limited understanding of competency-based education amongst academic staff and policymakers, as well as cultural and political influences on how people respond to change (e.g., hierarchy and bureaucracy are barriers to curriculum development in some ASEAN countries). Supporting systems and policy at the ASEAN level were seen as lacking.

Resources required for evidence-based dentistry. Evidence-based dentistry (EBD) is important for providing high quality oral health care and improving the patient's well-being. ${ }^{29}$ While instruction in EBD is preferable in a dental curriculum, it requires infrastructure and institutional support to enhance the practice of EBD. Specifically, EBD requires information-searching and access to published evidence, but most ASEAN dental schools do not have sufficient resources to support EBD.

The challenges of educational quality assurance processes. In some ASEAN countries, private dental schools are driven by profit-making and are not regulated and accredited by government bodies. The quality of the curricula and graduates of these schools remains unreported. Standards for regulating dental schools at the national or ASEAN level are needed. Conversely, in some countries (such as the United Kingdom), there are numerous national bodies regulating dental schools and their curricula, duplicating the information required. Many frameworks in education are developed based on the industrial model, which focuses on administration and service functions rather than quality of education. ${ }^{30}$ Normally evidence needs to be prepared in the form of documentation, ${ }^{31}$ and in many ASEAN dental schools, educators perceive this as simply extra paperwork, which results in dental schools' being burdened by requirements that stifle their opportunities for development.

Distribution and shortage of dental practitioners. In some areas of some countries (e.g., Philippines and Thailand), there is a shortage of dental patients suitable for students. This shortage could be a result of the uneven distribution of dental practices (e.g., lack of dental caries in big cities as there is an ample supply of dental practitioners working there) or a result of the availability of advanced/alternative treatment options for patients (e.g., a patient requests 
a dental implant instead of a bridge or denture). Such shortages can compromise the quality of work dental graduates perform as they may lack experience and competence in some areas of dental practice. This situation may also lead to innovative solutions such as placing outreach centers in areas of high dental need but low dental supply.

Policy and administration regarding dental education in ASEAN countries. There is variation in the process of dental education policy development in ASEAN countries. For example, in some countries (e.g., Malaysia), the ministry of health, the ministry of education, and dental schools work together at the policy level, while in other countries these three bodies work separately. This variation could affect how each country implements the common competencies.

\section{Implications and Recommendations}

The "Common Major Competencies for ASEAN General Dental Practitioners" can be used for many purposes. They help AJCCD to establish policies raising the quality of oral health care provided by general dentists graduating from ASEAN member states. They can also be used to define what to teach (curriculum content), how to teach (teaching/learning strategies), how to assess students (assessment strategies), how to assist students' learning (support), and how to set up infrastructure and environment to support students (educational environment). ${ }^{4,32}$

The ASEAN competencies are thus the primer for curriculum development and revisions across ASEAN dental schools. To achieve curriculum reform, ASEAN dental schools and their staffs need to gain deeper understanding of educational principles to support the implementation of competency-based education. Dental educators who have expertise in education are urgently required. The AJCCD should establish standards or strategies to improve the quality of dental curricula and of educators. To fully support free movement of dentists within ASEAN, the ASEAN competencies should also be used as a framework for developing curriculum standards, setting educational standards and benchmarking, guiding research in relation to ASEAN undergraduate dental education, tailoring staff/faculty development programs, and promoting staff and student exchange programs within ASEAN. ${ }^{9}$
However, it is important to be aware that the competencies developed at this stage only provide a set of minimum standards to support ASEAN dental schools to work toward harmonization of ASEAN dental education. Additionally, the ASEAN competencies were developed solely based on the policymaker (ASEAN Dental Councils) perspective, which was driven by society needs. Input from service providers (dental schools) and other stakeholders (e.g., students, allied dental professions) is required to improve the comprehensiveness of the ASEAN competencies. Further input from these groups will also be needed to add details to curriculum development and the supporting competency statements. Thus, the AJCCD should continue working with dental schools, dental practitioners, and professional bodies to support implementation of the ASEAN competencies at the local level. Regarding oral health problems in ASEAN and factors influencing ASEAN dental education, the representatives provided several recommendations for future development (Table 4).

\section{Conclusion}

The issue of harmonization of ASEAN undergraduate dental education to support free movement of dental practitioners and improve the quality of dental services within the region has been discussed at the policymaker level for decades. Recently, the ASEAN Dental Councils developed and established "Common Major Competencies for ASEAN General Dental Practitioners" to assist the harmonization process. The ASEAN competencies are the foundation of further educational development processes, including curriculum development, standards development, and staff and academic development. The successful harmonization of ASEAN undergraduate dental education relies on collaboration amongst the AJCCD, dental schools, other stakeholders, and the entire ASEAN community.

\section{Acknowledgments}

This research project was funded by the ASEAN Studies Center, Chulalongkorn University, Thailand. The authors would like to thank all the AJCCD members, the ASEAN Dental Councils, and their representatives who took the time to participate and complete the questionnaires in this study. 


\section{Table 4. Recommendations for future development of ASEAN dental education}

ASEAN Problem

Lack of prevention of oral diseases and oral health promotion in relation to dental caries, periodontal diseases, and pulpal and periapical diseases

High prevalence of tooth loss caused by untreated dental caries and periodontal disease and high prevalence of dental trauma caused by accidents and violence

Uneven distribution of oral health problems

Insufficient resources to support evidence-based dentistry (EBD)

Under-/overregulated dental curricula

Variation in the process of dental education policy development in each ASEAN country
Recommendation

ASEAN dentists should be competent in not only providing treatment and management of dental caries, periodontal diseases, and pulpal and periapical diseases but also prevention of these conditions. ASEAN undergraduate dental curricula should emphasize prevention and promotion aspects more in order to improve patients' oral health status.

The ability of ASEAN dentists to treat and manage tooth loss as well as manage oral and maxillofacial surgery problems is essential.

ASEAN dental practitioners should be able to manage a wide range of oral health problems appropriately. For dentists who practice in an area where specific oral diseases are common, an ability to provide treatment and prevention is required.

The implementation of EBD may vary in each dental school. Dental schools need to share resources in order to deliver effective EBD.

Agreement that a single regulatory body to assess the quality of dental curricula for each country, overseen by an appropriate ASEAN body, is required.

The harmonization of ASEAN dental education needs to extend beyond the educational context to include the political context.

Note: These definitions of problems and recommendations were developed by representatives of the Dental Councils of ASEAN member states.

\section{Disclosure}

The authors reported no conflicts of interest.

\section{REFERENCES}

1. Association of Southeast Asian Nations. At: asean.org/ asean/about-asean/overview/. Accessed 6 Sept. 2016.

2. ASEAN mutual recognition arrangement on dental practitioners. 2009. At: investasean.asean.org/files/upload/ MRA\%20Dental\%20Practitioner\%20\%28Feb09\%29. pdf. Accessed 6 Sept. 2016.

3. DePaola DP. The revitalization of U.S. dental education. J Dent Educ 2008;72(2 Suppl):28-42.

4. Chuenjitwongsa S. Competence, competency-based education, and undergraduate dental education: a discussion paper. Eur J Dent Educ, forthcoming.

5. American Dental Education Association. ADEA competencies for the new general dentist. J Dent Educ 2016;80(7):825-8.

6. Cowpe J. Profile and competences for the graduating European dentist, update 2009. Eur J Dent Educ 2010;14(4):193-202.

7. National Dental Examining Board of Canada. Competencies for a beginning dental practitioner in Canada. 2005. At: ndeb-bned.ca/sites/ndeb/files/pdf/competencies_2005final.pdf. Accessed 9 Sept. 2016.

8. Commission on Dental Accreditation. Accreditation standards for dental education programs. Chicago: American Dental Association, 2016.
9. Poolthong S, Chuenjitwongsa S. Facilitating the movement of qualified dental graduates to provide dental services across ASEAN member states. In: Sasaki K, Suzuki O, Takahashi N, eds. Interface oral health science 2016: innovative research on biosis-abiosis intelligent interface. Singapore: Springer Singapore, 2016.

10. Australian Dental Council. Professional competencies of the newly qualified dentist. 2016. At: www.adc.org.au/ documents/Professional\%20Competencies $\% 20$ of $\% 20$ the $\% 20$ Newly $\% 20$ Qualified $\% 20$ Dentist $\% 20-\% 20$ February\%202016.pdf. Accessed 9 Sept. 2016.

11. Manogue M. Curriculum structure, content, learning, and assessment in European undergraduate dental education: update 2010. Eur J Dent Educ 2011;15(3):133-41.

12. Keeney S. The Delphi technique in nursing and health research. Chichester, UK: Wiley-Blackwell, 2011.

13. Powell C. The Delphi technique: myths and realities. J Adv Nurs 2003;41(4):376-82.

14. Japan Universities Association for Computer Education. Competency of new Japanese dentist. 2010. At: www.juce. $\mathrm{jp} /$ senmon/dent/competency/Competency_of_New_Japanese Dentist2010-03.pdf. Accessed 9 Sept. 2016.

15. Okoli C, Pawlowski SD. The Delphi method as a research tool: an example, design considerations, and applications. Inform Manag 2004;42(1):15-29.

16. Macdonald EB. Requirements for occupational medicine training in Europe: a Delphi study. Occup Environ Med 2000;57(2):98-105. 
17. Manual of dental practice, version 5. 2014. At: www. eudental.eu/component/attachments/attachments. html?task=download\&id=1366. Accessed 3 March 2015.

18. World Health Organization. Strategy for oral health in South-East Asia, 2013-20. 2013. At: apps.who.int/iris/ bitstream/10665/205929/1/B5099.pdf. Accessed 9 Sept. 2016.

19. World Health Organization. World health statistics, 2015. At: apps.who.int/iris/bitstream/10665/170250/ 1/9789240694439_eng.pdf?ua=1. Accessed 9 Sept. 2016.

20. Chi AC. Oral cavity and oropharyngeal squamous cell carcinoma: an update. CA Cancer J Clin 2015;5(5): 401-21.

21. Brondani MA, Pattanaporn K. Integrating issues of substance abuse and addiction into the predoctoral dental curriculum. J Dent Educ 2013;77(9):1108-17.

22. Sood P. Dental patients' knowledge and perceptions about the effects of smoking and role of dentists in smoking cessation activities. Eur J Dent 2014;8(2):216.

23. Slavkin HC. Evolution of the scientific basis for dentistry and its impact on dental education: past, present, and future. J Dent Educ 2012;76(1):28-35.

24. Reynolds PA. Nine years of DentEd: a global perspective on dental education. Br Dent J 2008;205(4):199-204.

25. Spallek H, Turner SP, Donate-Bartfield E, et al. Social media in the dental school environment, part A: benefits, challenges, and recommendations for use. J Dent Educ 2015;79(10):1140-52.

26. Oliver R. Curriculum structure: principles and strategy. Eur J Dent Educ 2008;12(Suppl 1):74-84.

27. Chambers DW. Competency-based dental education in context. Eur J Dent Educ 1998;2(1):8-13.

28. UK Committee of Postgraduate Dental Deans and Directors. COPDEND standards for dental educators. 2013. At: www.copdend.org/data/files/Downloads/COPDEND_Standards\%20high\%20resolution.pdf. Accessed 3 March 2015.

29. Winning T. Evidence-based care and the curriculum. Eur J Dent Educ 2008;12(Suppl 1):48-63.

30. Becket N, Brookes M. Quality management practice in higher education: what quality are we actually enhancing. J Hospitality Leisure Sport Tourism Educ 2008;7(1):4054.

31. Standards and guidelines for quality assurance in the European Higher Education Area. 2005. At: www.enqa. eu/wp-content/uploads/2013/06/ESG_3edition-2.pdf. Accessed 3 March 2015.

32. Harden RM. Outcome-based education: part 1, an introduction to outcome-based education. AMEE guide no. 14. Med Teac 1999;21(1):7-14. 